\section{Degradation of Fibrin and Elastin by Intact Human Alveolar Macrophages In Vitro Characterization of a Plasminogen Activator and Its Role in Matrix Degradation}

\author{
Harold A. Chapman, Jr., O. Lee Stone, and Zdenek Vavrin \\ Departments of Medicine, University of Utah and Veterans \\ Administration Medical Center, Salt Lake City, Utah 84148
}

A

bstract. Fibrin deposition is prominent in the histopathology of a number of inflammatory lung diseases. Plasmin, activated locally in the lung, can degrade not only this fibrin but potentially structural proteins important to normal lung architecture. Because alveolar macrophages are prominent in inflammatory processes of the lung, we examined the plasminogen activator (PA) activity of human alveolar macrophages. Intact alveolar macrophages from each of 10 healthy subjects expressed PA activity. There was no difference in activity between smoking and nonsmoking individuals. The activator activity was largely cell-associated, but under certain culture conditions, macrophages released a soluble activator into the culture medium. The membrane-bound activator had an apparent molecular mass of 52-55 $\mathrm{kD}$ in nonreduced sodium dodecyl sulfate (SDS) gels, and monospecific antibody to urokinase neutralized the enzyme activity. Immunoprecipitation of $\left[{ }^{35} \mathrm{~S}\right]$ methionine-labeled cells showed that human alveolar macrophages actually synthesize the PA in vitro. SDS-gel analysis of the immunoprecipitated material revealed the predominant species of PA to be structurally similar to reduced, active urokinase. We also examined the role of PA in the degradation of both insoluble fibrin and elastin matrices by live macrophages. Cells degraded an insoluble fibrin matrix in the presence of plasminogen whether or not the macrophages contacted the fibrin as long as proteinase inhibitors were not in the culture medium. In the presence of serum proteinase inhibitors, macrophages still degraded a fibrin matrix, but only if they were in contact with the

Received for publication 1 August 1983 and in revised form 23 November 1983.

J. Clin. Invest.

(c) The American Society for Clinical Investigation, Inc. 0021-9738/84/03/0806/10 \$1.00

Volume 73, March 1984, 806-815 fibrin. Live macrophages also degraded insoluble elastin only when in contact with the elastin but could do so even in the presence of serum proteinase inhibitors. In matrices containing a mixture of fibrin and elastin, cells did not degrade elastin unless plasminogen was added to the medium. These results indicate that normal alveolar macrophages synthesize and express, probably at the cell surface, a PA. The PA is physically and immunochemically similar to urokinase but is membrane bound. The PA is critical to the degradation of fibrin matrices by normal alveolar macrophages. Under tissue conditions where elastin is embedded within other structural proteins, the activator may be rate-limiting in elastin degradation as well. The findings also suggest that live macrophage proteolytic activity is relatively insensitive to the presence of serum proteinase inhibitors, suggesting a mechanism for proteolytic lung injury even in the presence of proteinase-proteinase inhibitor balance in the soluble phase.

\section{Introduction}

Plasminogen activator (PA), ${ }^{1}$ by limited proteolysis of its major macromolecular substrate, plasminogen, subserves a number of biological roles. Plasmin generation is clearly important in the resolution of fibrin deposited in the vasculature (1). In this case, the major sources of PA are precursors circulating in blood and endothelial cells (2-4). Plasmin is also important to the degradation of fibrin deposited in tissues at inflammatory sites. A number, if not all, inflammatory cells elaborate PA (5-7). In addition, there is a strong correlation between the motility of such noninflammatory cells as oocytes and neurons and their expression of PA activity $(8,9)$. This association suggests plasmin may be important to the degradation of basement membrane and extracellular matrix proteins as well as fibrin. Vassalli et

1. Abbreviations used in this paper: DME, Dulbecco's modified Eagle's medium; $\mathbf{P A}$, membrane-associated PA; plg, plasminogen; PA, plasminogen activator; $\mathrm{PA}_{\mathbf{3}}$, soluble $\mathrm{PA}$. 
al. (10) have thus proposed PA via plasmin formation to be critical to the migration of cells through tissue barriers.

As might be expected, macrophages have the potential to express PA activity (11). In mice, the PA activity correlates with the activation state of the macrophages (12). Recently, we observed that stimulated mouse peritoneal macrophages express both a membrane-bound, cell surface $\mathrm{PA}\left(\mathrm{PA}_{\mathrm{m}}\right)$ as well as a soluble PA ( $\mathrm{PA}_{\mathrm{s}}$ ) (13). The $\mathrm{PA}_{\mathrm{m}}$ activity is important to the fibrinolytic activity of the cell because $\mathbf{P A}_{\mathrm{m}}$ is relatively resistant to soluble proteinase inhibitors also secreted by macrophages. Plasmin once bound to fibrin has a threefold order of magnitude decrease in its sensitivity to the major blood antiplasmin, $\alpha-2$ antiplasmin (14). Thus, murine macrophages can degrade a fibrin matrix in the presence of proteinase inhibitors by focusing fibrinolysis at or near the cell surface. Whether human macrophages have a similar fibrinolytic mechanism is unknown.

In this study, we examined the fibrinolytic activity of human alveolar macrophages. We first examined the enzymatic pathways by which these cells degrade fibrin. We then determined the ability of live cells to express this enzyme activity when cultured with protein matrices where other factors such as cell contact with the matrix and serum proteinase inhibitors could influence degradative capability. Lastly, we questioned whether the enzymes of fibrin degradation could modulate the degradation of other structural proteins by intact macrophages. For these experiments we used purified insoluble elastin, a protein of known importance to normal lung architecture (15) and for which no reported data are available regarding intact human alveolar macrophage degradative capability.

\section{Methods}

Bronchoalveolage lavage and cell preparation. Healthy community volunteers underwent fiberoptic bronchoscopy (Olympus B2, Olympus Corp. of America, Medical Instruments Div., New Hyde Park, NY) by standard techniques following written, informed consent as approved by a local institutional review board. Bronchoalveolar lavage fluid, $\sim 100 \mathrm{ml}$ of returned fluid from lingular segments, was mixed with an equal volume of cold tissue culture medium and centrifuged at $200 \mathrm{~g}$ for $8 \mathrm{~min}$ at $4^{\circ} \mathrm{C}$. The basic tissue culture medium used in all of the experiments in this study was Dulbecco's modifed Eagle's medium (DME). The pooled cellular pellets were counted by hemocytometer and washed in DME. The cells were then immediately used for experiments. Differential cell counting was done on a Giemsa-stained cytocentrifuge preparation. Differential counting revealed percentages of macrophages, lymphocytes, and neutrophils consistent with that previously reported for normal volunteers by other investigators $(16,17)$.

Reagents. Animal and human sera were prepared and stored as previously described (13). Human plasminogen (plg) was obtained from Helena Laboratories (Beaumont, TX) and was determined to be free of detectable plasmin in a ${ }^{125}$ I-fibrin plate assay at concentrations used in the experiments. Urokinase, obtained from the American Red Cross (Washington, DC), was stored at $-70^{\circ} \mathrm{C}$. Urokinase was radiolabeled with carrier-free ${ }^{125} \mathrm{I}$ (New England Nuclear, Boston, MA, $17 \mathrm{Ci} / \mathrm{mg}$ ) by a chloramine-T method (18). The unbound ${ }^{125}$ I was removed by sieve chromatography (Sephadex G-10) in the presence of $1 \mathrm{mg} / \mathrm{ml}$ bovine serum albumin carrier and the labeled urokinase aliquoted and stored at $-70^{\circ} \mathrm{C}$. Human fibrinogen was obtained from Merck Chemical Div., Merck \& Co. (Rahway, NJ) and made plg-free by repeated ethanol precipitation in the presence of lysine (19). ${ }^{125}$ I-Fibrinogen was obtained from Amersham Corp. (Arlington Heights, IL). Bovine ligamentum elastin was obtained from Elastin Products Co., Pacific, MO) and tritiated by reductive alkylation with $\left[{ }^{3} \mathrm{H}\right]$ borohydride (New England Nuclear) as described by Gordon et al. (20). The radiolabeled elastin was washed until the washings contained $<1 \%$ of the total radioactivity, aliquoted, and stored at $-70^{\circ} \mathrm{C}$. Sodium dodecyl sulfate (SDS) was obtained from Gallard-Schlesinger Chemical Mfg. Corp. (Carle Place, NY). All other reagents were of the highest grade commercially available.

Assays of $P A$. Intact cell fibrinolytic activity was assayed by culturing alveolar cells directly on ${ }^{125}$ I-fibrin-coated tissue culture wells. The plates were prepared as previously described, with some modifications (13). Microtiter plates (Falcon Labware Div., Becton-Dickinson \& Co., Oxnard, CA) were used in place of 16-mm culture wells. Each microtiter well contained $40 \mu \mathrm{g}$ of fibrinogen and $\sim 10,000 \mathrm{cpm}$ releasable by $0.25 \%$ trypsin. Before use the fibrinogen was converted to fibrin by incubation with thrombin (Sigma Chemical Co., St. Louis, MO), $\mathrm{IU} / \mathrm{ml}$, for $1 \mathrm{~h}$ at $37^{\circ} \mathrm{C}$. Preliminary experiments indicated that $10^{5}$ cells/culture chamber hydrolyzed $20-50 \%$ of the total fibrin in a $4-\mathrm{h}$ assay at $37^{\circ} \mathrm{C}$. Subsequently, $10^{5} \mathrm{cells} /$ well in triplicate were used for all assays. After adherence for $1 \mathrm{~h}$ at $37^{\circ} \mathrm{C}$, the cells were washed with phosphate-buffered saline (PBS) and incubated for $4 \mathrm{~h}$ in $100 \mu \mathrm{l}$ of serum-free tissue culture medium with or without supplemental human $\mathrm{plg}, 8 \mu \mathrm{g} / \mathrm{ml}$. Degraded fibrin was assayed by $\beta$-scintillation of $50-\mu \mathrm{l}$ aliquots of the culture media. Under these culture conditions urokinase, $0.8 \mathrm{IU} /$ well, hydrolyzed $45 \%$ of the total fibrin in $4 \mathrm{~h}$ and $0.05 \mathrm{IU} /$ well hydrolyzed $2 \%$ of the total fibrin. The assay was linear with respect to urokinase activity from 0 to $1 \mathrm{U} /$ well. In addition, alveolar cells were examined for release of $\mathrm{PA}_{\mathrm{s}}$ after overnight culture of cells $\left(10^{6} \mathrm{cells} /\right.$ 16-mm plastic culture well) in $400 \mu \mathrm{l}$ of either serum-free medium (DME) or medium supplemented with $1 \%$ dog or $1 \%$ acid-treated plgfree dog serum. The cell-free supernatants $(100 \mu \mathrm{l})$ were assayed for $\mathrm{PA}_{\mathbf{s}}$ by incubation in ${ }^{125} \mathrm{I}$-fibrin-coated wells with or without $\mathrm{plg}, 8 \mu \mathrm{g} / \mathrm{ml}$, as described above. PA activity is expressed as mean counts per minute released \pm standard error of the mean of triplicate determinations and as percent total fibrin degraded in $4 \mathrm{~h}$.

Molecular weight analysis of macrophage $\mathrm{PA}_{\mathrm{m}}$ was done by direct assay of PA in gel slices following SDS-gel electrophoresis (21). $48 \times 10^{6}$ total cells, $>95 \%$ macrophages, lavaged from a smoking subject were mechanically hornogenized in $0.25 \mathrm{M}$ sucrose, $10 \mathrm{mM}$ Tris, $1 \mathrm{mM}$ EDTA, pH 7.4, a.td centrifuged at $1,500 \mathrm{~g}$ to remove nuclei and fragmented cells. A membrane fraction was then prepared by centrifugation at $100,000 \mathrm{~g}$ for $90 \mathrm{~min}$ at $4^{\circ} \mathrm{C}$. The fraction contains microsomal, granule, and plasma membrane elements (22). The preparation was repeated with cells from four additional smokers and in two of these subjects additional proteinase inhibitors $(100 \mathrm{U} / \mathrm{ml}$ trasylol and $1 \mathrm{mM}$ phenylmethanesulfonyl fluoride) were added to the homogenizing buffer. The membrane fraction was dissolved in $3 \%$ SDS, $10 \%$ glycerol, 0.0625 $\mathrm{M}$ Tris, $\mathrm{pH} 6.3$, and the membrane equivalent of $12 \times 10^{6}$ cells electrophoresed in triplicate in $10 \%$ acrylamide SDS gels at room temperature. A nonreducing Laemmli buffer system was used for electrophoresis (23). The gels were soaked in $0.5 \%$ Triton $\mathrm{X}-100$ in PBS $(\mathrm{pH} \mathrm{7.4)}$ for $1 \mathrm{~h}$, then $2 \mathrm{~h}$ in $\mathrm{H}_{2} \mathrm{O}$, and then cut into $1-\mathrm{mm}$ slices. The 1-mm gel slices were assayed for PA activity in ${ }^{125}$ I-fibrin-coated microtiter wells. Because large amounts of plg were necessary in these experiments, we used $1 \%$ acid-treated dog serum in $200 \mu \mathrm{l} \mathrm{DME/well} \mathrm{as} \mathrm{a} \mathrm{source} \mathrm{of} \mathrm{plg.} \mathrm{No} \mathrm{fibrin}$ 
degradation occurred in the absence of supplemental plg. Companion gel slices, generally 6-8, from the region determined to contain PA were also examined for cross-reaction with antibody to urokinase as judged by neutralization of PA activity. In these experiments, PA was assayed in ${ }^{125}$ I-fibrin-coated microtiter chambers containing $200 \mu$ l PBS or PBS with various dilutions of urokinase antibody. Purified urokinase or streptokinase empirically adjusted to equivalent PA activity as that of the gel slices $(0.1 \mathrm{U} /$ well and $0.01 \mathrm{U} /$ well, respectively) served as controls. Human plg, $8 \mu \mathrm{g} / \mathrm{ml}$, was then added to all wells. Fibrin degradation was assayed following $10-18 \mathrm{~h}$ at $37^{\circ} \mathrm{C}$ by $\beta$-scintillation of $100-\mu \mathrm{l}$ aliquots and data is expressed as percentage of PA activity without antibody.

Elastase assays. Elastase activity was assayed by solubilization of $\left[{ }^{3} \mathrm{H}\right]$ elastin (bovine ligamentum nuchae) in the absence of detergent. $\left[{ }^{3} \mathrm{H}\right]$ Elastin suspended in water was sonicated in a Branson 350 sonicator (Branson Sonic Power, Co., Danbury, CT) using a microprobe for $45 \mathrm{~s}$ at room temperature in the pulse mode at the lowest energy setting and then dried in 16-mm culture wells (Costar, Data Packaging, Cambridge, $\mathrm{MA}$ ) at $47^{\circ} \mathrm{C}$. Although sonicated, the elastin appeared mostly particulate by phase and scanning electron microscopy. Each well contained $\sim 240,000 \mathrm{cpm}$ releasable by porcine pancreatic elastase (type III, Sigma Chemical Co.). The specific activity of the $\left[{ }^{3} \mathrm{H}\right]$ elastin was $1,200 \mathrm{cpm} /$ $\mu \mathrm{g}$ protein. Plasmin, $25 \mu \mathrm{g} / \mathrm{ml}$, dissolved in DME solubilized $<0.1 \%$ of the total radioactivity of $\left[{ }^{3} \mathrm{H}\right]$ elastin-coated chambers after $24 \mathrm{~h}$ at $37^{\circ} \mathrm{C}$. The chambers were washed in PBS and intact alveolar macrophages adhered directly to the elastin-coated culture wells $\left(10^{6}\right.$ cells/well $)$. The cells appeared by phase microscopy to adhere both to the elastin and to the exposed plastic surfaces. The cells in duplicate were incubated in $400 \mu \mathrm{l}$ of DME containing various additives for $24 \mathrm{~h}$ at $37^{\circ} \mathrm{C}$. Following the culture period, $300 \mu \mathrm{l}$ of culture media was removed, spun at 10,000 $g$ in a microfuge, and $100-\mu l$ aliquots were assayed for degraded elastin by $\beta$-scintillation. Elastase activity is expressed as nanograms elastin solubilized in duplicate determinations per $24 \mathrm{~h}$ per $10^{6}$ cells. Under the culture conditions described, porcine pancreatic elastase, $0.1 \mu \mathrm{g} / \mathrm{ml}$, released $32 \mu \mathrm{g}$ and $0.01 \mu \mathrm{g} / \mathrm{ml}$ released $2 \mu \mathrm{g}$ elastin in $24 \mathrm{~h}$ at $37^{\circ} \mathrm{C}$.

The role of cell contact in macrophage-mediated fibrin or elastin degradation was assayed by co-culture of macrophages in chambers containing ${ }^{125} \mathrm{I}$-fibrin or $\left[{ }^{3} \mathrm{H}\right]$ elastin or a mixture of unlabeled fibrin and $\left[{ }^{3} \mathrm{H}\right]$ elastin. The cells were either in contact with or removed from the protein matrices but, in either case, shared the same culture medium. To accomplish this, we spread and dried the protein substrates $(40 \mu \mathrm{g}$ fibrinogen, $100 \mu \mathrm{g}\left[{ }^{3} \mathrm{H}\right]$ elastin) on only one-half the surface area of the culture chamber (16 mm, Costar Data Packaging). In the case of fibrin and elastin mixtures, the fibrin appeared by scanning electron microscopy to coat the elastin, and very little fibrin was observable in its typical protomeric structure in the presence of the elastin (24). After drying, the matrices were washed with PBS, the fibrinogen converted to fibrin, and the intact alveolar macrophages adhered either on or off the matrices by tilting the culture chambers during adherence. By alternating the halves of the culture well coated with fibrin and/or elastin, cells could be adhered both on and off the protein matrices in a single 24-well culture plate. After adherence, the cell monolayers were washed, the plates gently placed flat, and then incubated in $500 \mu \mathrm{l}$ of medium in standard fashion. By microscopy, at the end of each experiment, we confirmed that $<0.1 \%$ of the total cells plated off the matrices migrated into the matrix during the culture period. Supernates were assayed for solubilized fibrin or elastin after $24-\mathrm{h}$ incubation at $37^{\circ} \mathrm{C}$ as described above.

Metabolic labeling of macrophages, immunoprecipitation, and autoradiography. Adherent human alveolar macrophages were metabolically labeled at a density of $10^{7}$ cells $/ 25 \mathrm{~cm}^{2}$ in a tissue culture flask (Falcon Labware), $4 \mathrm{ml}$ medium/flask. A total of $\sim 40 \times 10^{6}$ cells obtained from smoking subjects were labeled in each of six experiments. After adherence, the cells were incubated for $2 \mathrm{~h}$ at $37^{\circ} \mathrm{C}$ in DME containing $10 \%$ fetal bovine serum. The cell monolayers were then washed and incubated for $18 \mathrm{~h}$ in $4 \mathrm{ml}$ of medium consisting of DME containing $10 \%$ of the stock methionine ( $0.02 \mathrm{mM}$ methionine), $0.5 \%$ fetal bovine serum, and $100 \mu \mathrm{Ci} / \mathrm{ml}\left[{ }^{35} \mathrm{~S}\right]$ methionine (New England Nuclear, $1,000 \mathrm{Ci} / \mathrm{mol} \mathrm{sp}$ act). After labeling, the cell monolayers were thoroughly washed in PBS, scraped, and pelleted by centrifugation. A membrane fraction of the macrophages containing all PA activity was prepared as described above and solubilized in PBS, pH 7.4, containing $0.1 \%$ SDS for subsequent immunoprecipitation. A urokinase antibody prepared in rabbits was obtained from Alpha Therapeutics Corp. (Los Angeles, CA) and used in immunoprecipitation experiments. The antibody contained IgG and some albumin contamination as defined by Coomassie Blue staining of electrophoresed antibody. Preliminary experiments indicated that the antibody would neutralize the PA activity of urokinase but not streptokinase in the fibrin plate assay. Also, the antibody immunoprecipitated ${ }^{125}$ I-urokinase in a specific fashion in that $2,500 \mathrm{U}$ of unlabeled urokinase blocked the precipitation of ${ }^{125}$ I-urokinase. Immunoprecipitation with irrelevant antisera or the urokinase antibody was done in successive steps (25). In the first step, solubilized cell membrane fractions or the ${ }^{125}$ I-urokinase, $100-\mu$ l each, in PBS plus $0.1 \%$ SDS were mixed with 15 $\mu l$ antisera to antithrombin III (rabbit, Calbiochem-Behring Corp., San Diego, CA). After $2 \mathrm{~h}$ at room temperature, IgG was absorbed with 150 $\mu \mathrm{l}$ of prewashed 10\% Staphylococcus aureus (IgG Sorb, Enzyme Center, Inc., Boston, MA) and discarded after centrifugation at $10,000 \mathrm{~g}$ to recover the samples. This step was performed to eliminate any nonspecific binding of radiolabeled cell protein to $S$. aureus. $15 \mu \mathrm{l}$ of the urokinase antibody was then added to the samples and the precipitation step repeated with fresh, prewashed $S$. aureus. The precipitated complexes were removed from the $S$. aureus in sample buffer for SDS-gel electrophoresis by boiling for $2 \mathrm{~min}$. The eluted proteins were then electrophoresed in $10 \%$ acrylamide slab gels under reducing conditions, dried, and autoradiographed for $14 \mathrm{~d}$ at $-70^{\circ} \mathrm{C}$ using Kodak-Xomat-AR film (Eastman Kodak Co., Rochester, NY).

Protein determination. Protein concentration was determined by the method of Lowry (26) using a bovine albumin standard.

\section{Results}

Fibrinolytic activity of human alveolar macrophages. Intact alveolar macrophages from each of 10 community volunteers cultured on ${ }^{125} \mathrm{I}$-fibrin-coated plastic culture wells measurably degraded the fibrin within $4 \mathrm{~h}$ of their explanation (Fig. 1). That this fibrinolytic activity was PA-dependent is indicated by the clear difference in fibrinolytic activity (percent total fibrin degraded) when plg was added to the culture medium. The mean percent fibrin degraded for all subjects in the presence or absence of plg was 47 and $7 \%$, respectively. The mean fibrinolytic activity of $10^{5}$ human alveolar macrophages in the presence of plg corresponded to that of $0.8 \mathrm{U}$ of urokinase under similar culture conditions. Seven of the subjects were nonsmokers, and three smoked an average of $1 \mathrm{pack} / \mathrm{d}$. There was no difference in PA activity between the two groups. We questioned whether the PA activity expressed by intact macrophages represented $\mathrm{PA}_{\mathrm{s}}$ and/or cell-associated activity. Macrophages from these 10 


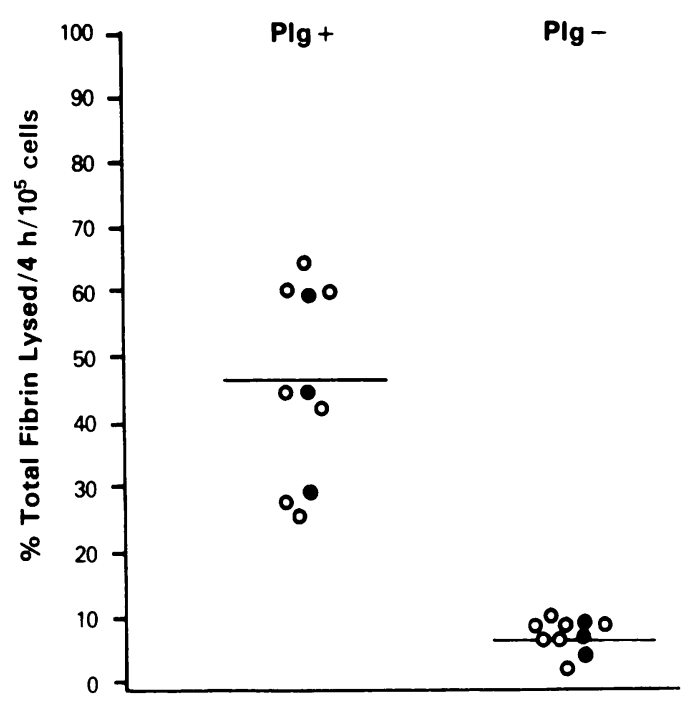

Figure 1. Fibrinolytic activity of human alveolar macrophages. Human alveolar macrophages from nonsmoking ( 0 ) or smoking individuals $(\bullet)$ were cultured on ${ }^{125} \mathrm{I}$-fibrin at $37^{\circ} \mathrm{C}$ in serum-free medium in the absence or presence of human $\mathrm{plg}, 8 \mu \mathrm{g} / \mathrm{ml}$. Aliquots of cell-free medium were assayed for fibrin degradation after $4 \mathrm{~h}$ at $37^{\circ} \mathrm{C}$. Data are expressed as mean percent total fibrin degraded in triplicate determinations. The bars, 47 and $7 \%$, represent the mean percent fibrin degraded by cells from all subjects cultured with or without plg, respectively.

subjects cultured overnight in serum-free DME or in DME supplemented with $1 \%$ dog or human serum did not release measurable $\mathbf{P A}_{\mathbf{s}}$. However, when we cultured macrophages in acid-treated serum instead of whole serum or serum-free medium, the results were different. Macrophages obtained from an additional four of six subjects (four smokers, two nonsmokers) and incubated in $1 \%$ acid-treated, plg-free dog serum did release variable but measurable amounts of $\mathbf{P A}_{\mathrm{s}}$ (Table I). By comparison with equivalent numbers of intact cells the $\mathrm{PA}_{\mathrm{s}}$ activity in 24-h conditioned medium was much less and corresponded to that of $0.06 \mathrm{U}$ of urokinase $/ 10^{5}$ cells.

We have previously studied the expression of PA by murine macrophages (13). We observed that endotoxin, $10-100 \mathrm{ng} / \mathrm{ml}$, added to macrophages in culture resulted in complete loss of $\mathrm{PA}_{\mathbf{s}}$ activity. Endotoxin did not block intact cell PA activity and instead actually increased membrane-bound PA. We tested the effect of endotoxin on PA release by human alveolar macrophages. As the data in Table I indicates, endotoxin $100 \mathrm{ng} /$ $\mathrm{ml}$ suppressed release of $\mathrm{PA}_{\mathrm{s}}$ by cultured human alveolar macrophages in the two subjects tested.

We considered the possibility that the low levels of $\mathrm{PA}_{\mathrm{s}}$ could represent contamination from PA released by human neutrophils. However, there was no difference in proportion of lavage cells that were neutrophils in secretors or nonsecretors, $<2 \%$ in both groups. The conditions under which cells released the PA were limited, i.e., acid-treated serum, and the amount was small as a fraction of the total cellular PA activity under even optimal conditions. Whether acid-treated serum stimulated PA release or factors in whole serum suppressed activity is unclear. Serum factors have been shown to modulate cell-derived PA activity in other experimental systems $(28,29)$.

Characterization of alveolar macrophage $P A$. Previous investigations of PA elaborated by cells in culture have characterized PA as urokinase-like or tissue activator-like on the basis of size (50-60 kD vs. 65-70 kD, respectively) and immunochemical cross-reactivity with antibody prepared against the parent activator (21). We determined the molecular mass of human alveolar macrophage $\mathrm{PA}_{\mathrm{m}}$ by direct assay of PA in gel slices following SDS-gel electrophoresis of a membrane fraction of the cell containing all PA activity. As Fig. 2 shows, only gel slices corresponding to 50-55 kD contained measurable PA activity. In five separate determinations from three smoking subjects, the peak PA activity migrated with an average, apparent molecular mass of $52 \mathrm{kD}$. The apparent molecular mass of PA was not influenced by the addition, in two subjects, of trasylol or phenylmethanesulfonyl fluoride to the cell lysing medium. Purified, nonreduced urokinase migrated with an apparent molecular mass of $53 \mathrm{kD}$ (data not shown).

The data in Fig. 2 suggested macrophage $\mathbf{P A}_{\mathrm{m}}$ was urokinase-like. We therefore performed experiments to determine if

Table I. Soluble PA Released by Human Macrophages

\begin{tabular}{|c|c|c|c|c|}
\hline \multirow[b]{2}{*}{ Subject } & \multirow[b]{2}{*}{ Endotoxin } & \multicolumn{2}{|c|}{$\begin{array}{l}{ }^{125} \text { I-Fibrin degraded } \\
\text { (cpm released) }\end{array}$} & \multirow[b]{2}{*}{ Urokinase } \\
\hline & & No plg & plg added & \\
\hline & & & & $\begin{array}{l}\text { Units released/ } \\
10^{6} \text { cells }\end{array}$ \\
\hline \multirow[t]{2}{*}{1 Smoker } & - & $55 \pm 5$ & $1,030 \pm 46$ & 0.64 \\
\hline & + & $44 \pm 6$ & $157 \pm 9$ & 0.02 \\
\hline \multirow[t]{2}{*}{2 Smoker } & - & $101 \pm 4$ & $603 \pm 21$ & 0.37 \\
\hline & + & $80 \pm 3$ & $356 \pm 26$ & 0.21 \\
\hline 3 Nonsmoker & - & $71 \pm 7$ & $1,008 \pm 30$ & 0.62 \\
\hline 4 Nonsmoker & - & $77 \pm 5$ & $369 \pm 21$ & 0.23 \\
\hline 5 Smoker & - & $40 \pm 4$ & $60 \pm 8$ & 0 \\
\hline 6 Smoker & - & $40 \pm 6$ & $65 \pm 7$ & 0 \\
\hline
\end{tabular}

Lavage cells were incubated, $10^{6}$ cells/16-mm culture well, in $400 \mu \mathrm{l}$ $1 \%$ acid-treated pig-free dog serum. After $18 \mathrm{~h}$ at $37^{\circ} \mathrm{C}$, cell-free supernates were transferred to ${ }^{125}$ I-fibrin-coated microtiter wells and incubated $4 \mathrm{~h}$ at $37^{\circ} \mathrm{C}$ with or without added plg, $8 \mu \mathrm{g} / \mathrm{ml}$. $50 \mu \mathrm{l}$ of medium was then assayed for radioactivity by $\beta$-scintillation. Data are expressed as mean counts per minute released \pm standard error of the mean and as urokinase units released per $10^{6}$ cells. In subjects $1-$ 4 , the fraction of total fibrin degraded by $4 \mathrm{~h}$ averaged $5-10 \%$ of total fibrin in the presence of plg. In these subjects, the assay was extended for an additional $20 \mathrm{~h}$ at $37^{\circ} \mathrm{C}$ and in all cases at least $60 \%$ of the total fibrin was then degraded. No degradation occurred in the absence of added plg. 


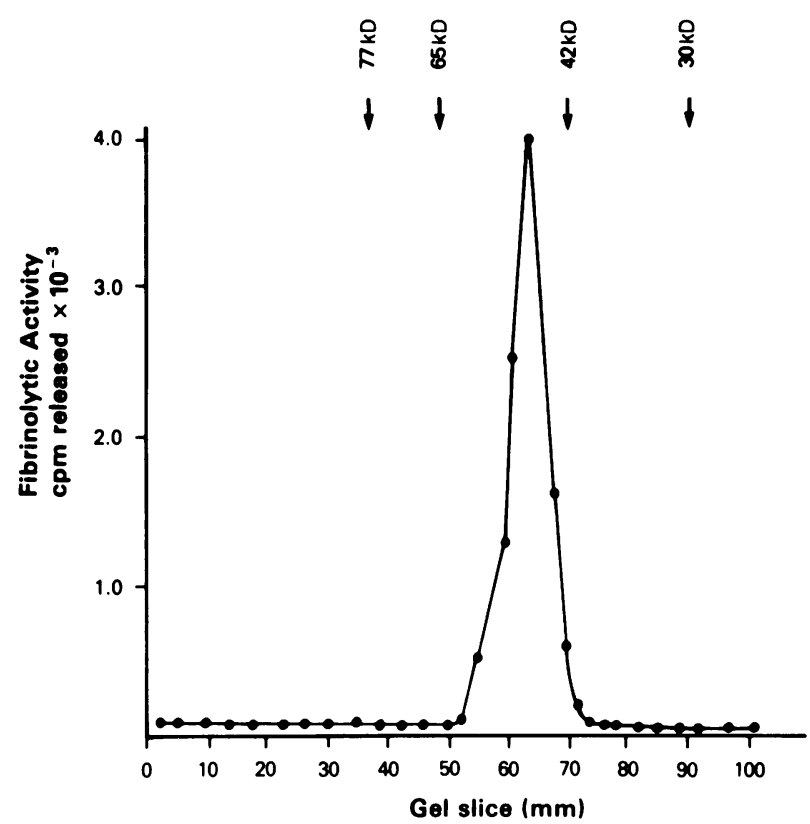

Figure 2. Molecular mass determination of human alveolar macrophage PA. A membrane fraction of human alveolar macrophages (12 $\times 10^{6}$ cells) was solubilized in SDS-containing buffer and run nonreduced in 10\% acrylamide-SDS slab gels. 1-mm gel slices were cut and assayed for PA activity by a ${ }^{125}$ I-fibrin plate assay. $1 \%$ acidtreated dog serum served as a source of plg. The data are expressed as percent fibrin degraded in the presence of plg for representative 1$\mathrm{mm}$ gel slices. No activity was seen in the absence of plg. The molecular mass standards were transferrin $(77 \mathrm{kD})$, albumin $(66 \mathrm{kD})$, actin $(42 \mathrm{kD})$, and carbonic anhydrase $(30 \mathrm{kD})$.

antibody prepared against human urokinase would neutralize macrophage PA activity. For these experiments we again prepared a membrane fraction of alveolar macrophages and subjected the solubilized material to SDS-gel electrophoresis. Gel slices from the region known to contain PA were then assayed for PA either in PBS containing purified plg, $8 \mu \mathrm{g} / \mathrm{ml}$, or in this medium to which various amounts of urokinase antibody were added. As controls, purified human urokinase or the immunologically unrelated streptokinase were adjusted empirically to concentrations of equivalent PA activity and assayed identically to the gel slices. Concentrations of urokinase antibody, which had no inhibitory effect on streptokinase activity, blocked $>80 \%$ of macrophage $\mathbf{P A}_{\mathrm{m}}$ and $70 \%$ of urokinase activity (Fig. 3). Higher concentrations of the antibody preparation neutralized all PA activities. This last observation likely reflects the known ability of IgG to compete with fibrin as a plasmin substrate (2l).

Immunoprecipitation of metabolically labeled alveolar macrophages. To further define the PA expressed by normal macrophages, we examined macrophages for their ability to synthesize the PA in culture. Human alveolar macrophages from two smoking subjects, $40 \times 10^{6}$ cells from each, were metabolically labeled in separate experiments for $18 \mathrm{~h}$ with $\left[{ }^{35} \mathrm{~S}\right]$ methionine. After removal of the label, we again prepared a cell fraction containing all $\mathrm{PA}_{\mathrm{m}}$ activity. We then immunoprecipitated the solubilized $\mathrm{PA}_{\mathrm{m}}$ preparation with urokinase antibody and analyzed the precipitated material by autoradiography after SDS-gel electrophoresis. Purified, ${ }^{125}$ I-labeled urokinase served as a reference antigen. The autoradiographs depicted in Fig. 4 show two proteins synthesized by macrophages and precipitated by the urokinase antibody $(A)$ that compare closely in size to the heavy and light chains of purified, reduced urokinase $(B)$. In addition, a rather heavily labeled material appears at the interface of the 5\% stacking and $10 \%$ separating gel $(\geq 250$ $\mathrm{kD}$ ) and three faint intermediate bands of 66,60 , and $50 \mathrm{kD}$ were also apparent. We observed identical results with a $\mathbf{P A}_{\mathbf{m}}$ preparation from a second smoking subject (data not shown).

Degradation of fibrin by intact human macrophages in the presence of soluble protease inhibitors. Intact normal alveolar macrophages lyse fibrin by a plg-dependent mechanism (Fig. 1). These experiments were done in medium free of proteinase inhibitors and with cells in contact with the fibrin. We next examined the ability of intact macrophages to degrade fibrin in the presence of proteinase inhibitors. We coincubated cells and fibrin in tissue culture chambers where cells either were in contact with or remote to the fibrin. We then tested the effect of various sera on the extent of fibrinolysis by macrophages on or off the substrate. Since plasmin does not bind to macrophages (unpublished observations) in either case the plasmin is free to

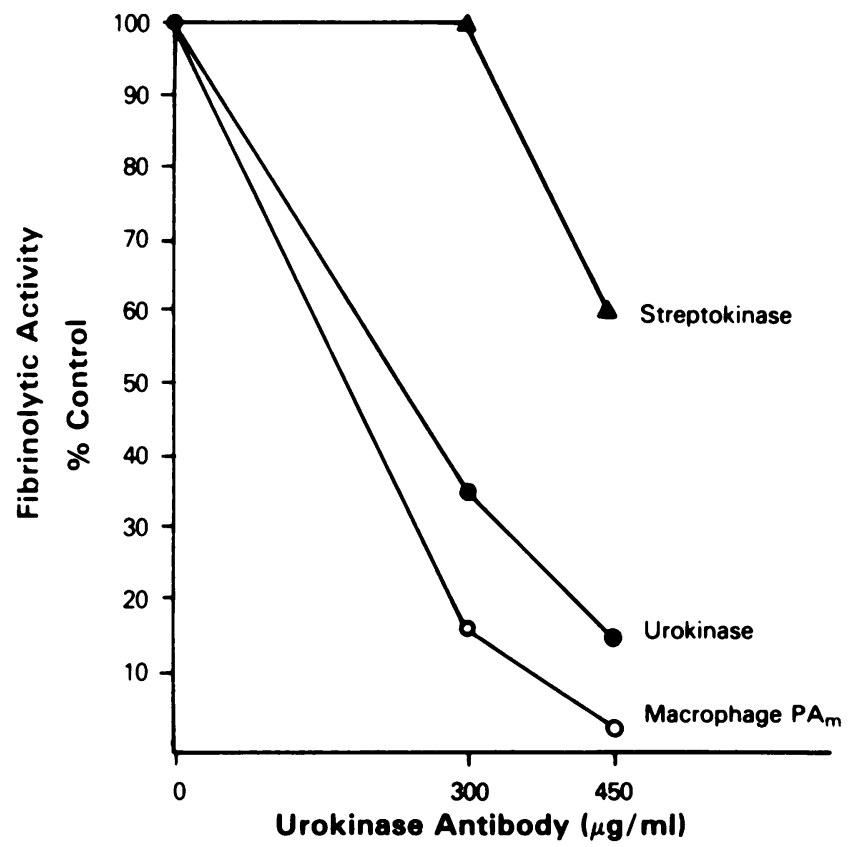

Figure 3. Effect of urokinase antibody on PA activity of human macrophages $\left(\mathbf{P A}_{\mathrm{m}}\right)$, urokinase, and streptokinase. $\mathbf{P A}_{\mathrm{m}}$ isolated by gel electrophoresis, urokinase $(0.1 \mathrm{IU})$, and streptokinase $(0.01 \mathrm{U})$ were tested for neutralization by urokinase antibody by mixing enzyme and antibody $(0,300,450 \mu \mathrm{g} / \mathrm{ml})$ in a ${ }^{125}$ I-fibrin plate assay. Activity is expressed for each enzyme as percentage of fibrinolysis in the absence of antibody. 


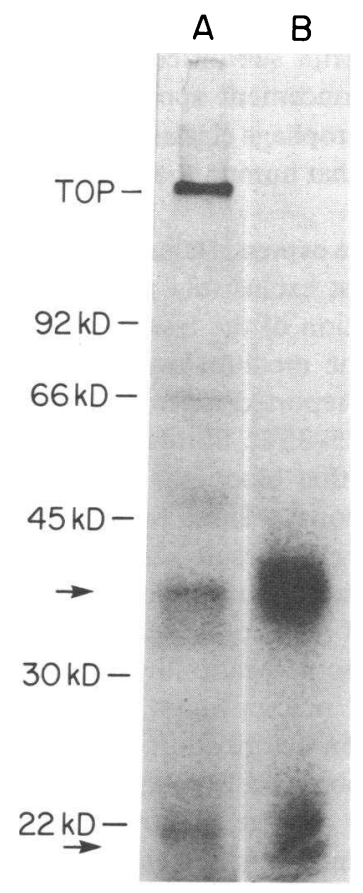

Figure 4. Immunoprecipitation of ${ }^{35} \mathrm{~S}-$ labeled human alveolar macrophages $(A)$ or purified, ${ }^{125} \mathrm{I}$-labeled urokinase $(B)$ by urokinase antibody. A membrane fraction of $4 \times 10^{7}$ alveolar macrophages containing all PA activity was prepared after metabolic labeling of the cells with ${ }^{35}$ S $]$ methionine. The figure shows autoradiographs of radiolabeled cell protein $(A)$ and of ${ }^{125}$ I-urokinase $(B)$ following immunoprecipitation by urokinase antibody and electrophoresis in SDS gels under reducing conditions. The arrows refer to labeled macrophage proteins corresponding closely in apparent molecular mass to the heavy and light chains of purified, reduced urokinase. The molecular mass standards were phosphorylase B (92 kD), bovine serum albumin (66 kD), ovalbumin (45 kD), carbonic anhydrase (30 kD), and soybean trypsin inhibitor ( $22 \mathrm{kD}$ ).

diffuse in the medium to the fibrin. The data in Table II show that macrophages incubated in tissue culture medium containing plg but depleted of proteinase inhibitors (by acid treatment) lysed the fibrin in an 18-h assay to an equivalent extent whether or not the cells were in contact with the fibrin. As before (Fig. 1), cells incubated in plg-free medium had much less fibrinolytic activity, whether or not the cells were in contact. Cells cultured in medium rich in proteinase inhibitors, either fetal bovine serum or human serum, only hydrolyzed the fibrin when in contact with the substrate. The extent of lysis by cells on fibrin was 11 and 7 times that of cells off the fibrin for fetal bovine serum and human serum, respectively. Notably, cells incubated on the fibrin matrix hydrolyzed the fibrin to a similar extent in an 18 - $\mathrm{h}$ assay whether or not proteinase inhibitors were in the medium. We should point out that the rate of degradation of fibrin was slower in either fetal serum or human serum than in serum-free medium, but fibrin was largely lysed in either case by $18 \mathrm{~h}$. We report the findings at $18 \mathrm{~h}$ to illustrate how little degradation occurs in even $18 \mathrm{~h}$ if cells are cultured remote to the substrate in medium containing proteinase inhibitors.

Elastin degradation by intact human alveolar macrophages. Human macrophages, especially those from smoking subjects, are known to contain elastase activity. At least part of this activity appears to be explained by neutrophil elastase on or within macrophages or by neutrophils contaminating the macrophage preparations (30). However, recently reported studies indicate that human monocytes express a membrane-bound elastase and that human monocyte-derived macrophages contain an elastase that is not neutrophil elastase $(31,32)$. Most assays of elastase activity utilize a detergent-treated elastin and, there- fore, assay either lysed cells or conditioned medium from cultured cells $(20,30,33,34)$. We have recently developed an assay of intact mouse macrophage elastase activity utilizing a sonicated, detergent-free $\left[{ }^{3} \mathrm{H}\right]$ elastin. We therefore examined what role, if any, PA and plg have in the degradation of $\left[{ }^{3} \mathrm{H}\right]$ elastin by intact human alveolar macrophages in this assay. Alveolar lavage cells from smoking individuals cultured directly on $\left[{ }^{3} \mathrm{H}\right]$ elastin matrices partially degraded the elastin, as judged by solubilized radioactivity (Table III). In five experiments the mean percent total elastin degraded in $24 \mathrm{~h}$ was $4 \%$, and this represented an average of $6.6 \mu \mathrm{g}$ of insoluble elastin degraded per $24 \mathrm{~h}$ per $10^{6}$ cells. This contrasts with release of 12-15 $\mu$ g elastin in $24 \mathrm{~h}$ by stimulated mouse macrophages at similar cell densities and culture conditions (Chapman, H. A., and O. L. Stone, manuscript submitted for publication). As previously reported by other investigators, cell lysates have little activity (30). The results were different with alveolar cells cultured on matrices containing a mixture of fibrin and elastin. Alveolar cells cultured on fibrin/ elastin matrices hydrolyzed little if any elastin in the absence of added plg, but degraded elastin similar to that observed with elastin-only matrices in the presence of plg (Table III). The ratio of fibrin to elastin in the experiments reported in Table III was $40 \mu \mathrm{g}$ fibrin/100 $\mu \mathrm{g}$ elastin. We observed similar findings with $20 \mu \mathrm{g}$ fibrin to $100 \mu \mathrm{g}$ elastin but did not otherwise vary the ratio of fibrin to elastin.

Table II. Effect of Cell Contact and Serum Proteinase Inhibitors on Degradation of ${ }^{125}$ I-Fibrin by Human Alveolar Macrophages

\begin{tabular}{|c|c|c|c|}
\hline \multirow[b]{2}{*}{$\begin{array}{l}\text { Serum added to basic } \\
\text { tissue culture medium }\end{array}$} & \multicolumn{2}{|c|}{$\begin{array}{l}{ }^{125} \text { I-Fibrin degraded } \\
\text { (cpm released) }\end{array}$} & \multirow[b]{2}{*}{$\begin{array}{l}\text { Ratio of lysis } \\
\text { on/off fibrin }\end{array}$} \\
\hline & $\begin{array}{l}\text { Cells on } \\
\text { fibrin }\end{array}$ & $\begin{array}{l}\text { Cells remote } \\
\text { to fibrin }\end{array}$ & \\
\hline $\begin{array}{l}\text { 1\% acid-treated, } \\
\text { plg-free dog } \\
\text { serum }\end{array}$ & $849 \pm 51$ & $150 \pm 67$ & 5.6 \\
\hline $\begin{array}{l}\text { 1\% acid-treated, } \\
\text { plg-free dog } \\
\text { serum plus plg, }\end{array}$ & & & \\
\hline $\begin{array}{l}8 \mu \mathrm{g} / \mathrm{ml} \\
1 \% \text { fetal bovine }\end{array}$ & $2,865 \pm 58$ & $2,732 \pm 44$ & 1.0 \\
\hline $\begin{array}{l}\text { serum } \\
1 \% \text { human serum, } \\
\text { MM } \alpha_{1^{-}} \\
\text {antitrypsin }\end{array}$ & $2,231 \pm 45$ & $202 \pm 6$ & 11.0 \\
\hline phenotype & $2,344 \pm 185$ & $230 \pm 16$ & 7.7 \\
\hline
\end{tabular}

Intact human alveolar macrophages $\left(5 \times 10^{5}\right.$ cells) from a smoking individual were incubated for $18 \mathrm{~h}$ at $37^{\circ} \mathrm{C}$ either on or off ${ }^{125} \mathrm{I}$-fibrin matrices in $0.5 \mathrm{ml}$ tissue culture medium containing $1 \%$ (vol/vol) various sera as shown in the table. Aliquots $(50 \mu \mathrm{l})$ of the medium were assayed for degraded fibrin and data are expressed as mean counts per minute \pm standard of the mean released after $18 \mathrm{~h}$ at $37^{\circ} \mathrm{C}$. Each culture well contained $3,500 \mathrm{cpm} / 50 \mu \mathrm{l}$ releasable by $0.25 \%$ trypsin. Similar results were obtained with macrophages from four additional subjects. 
Table III. Degradation of $\left[{ }^{3} \mathrm{H}\right]$ Elastin by Intact Human Alveolar Macrophages Role of plg and PA

\begin{tabular}{lllc}
\hline & & \multicolumn{2}{c}{$\begin{array}{c}\left.{ }^{3} \mathrm{H}\right] \text { Elastin degraded } \\
(\mathrm{ng} / 24 \mathrm{~h})\end{array}$} \\
\cline { 3 - 4 } Enzyme source & $\begin{array}{l}\text { Plg } \\
\text { added }\end{array}$ & $\begin{array}{l}\text { Elastin } \\
\text { only }\end{array}$ & $\begin{array}{l}\text { Fibrin/elastin } \\
\text { matrix }\end{array}$ \\
\hline Intact cells & - & 5,879 & 425 \\
& + & 7,349 & 8,725 \\
Cell lysates & - & 898 & 700 \\
& + & 1,747 & 731 \\
Pancreatic elastase & & & ND \\
$1 \mathrm{ng} / \mathrm{ml}$ \\
$10 \mathrm{ng} / \mathrm{ml}$
\end{tabular}

Human alveolar macrophages $\left(10^{6}\right.$ cells) or an equivalent number of lysed cells $\left(0.2 \%\right.$ Triton in PBS) were cultured on $\left[{ }^{3} \mathrm{H}\right]$ elastin or fibrin $/\left[{ }^{3} \mathrm{H}\right]$ elastin matrices in DME containing $1 \%$ plg-free, acid-treated dog serum as described in the text. After $24 \mathrm{~h}$ at $37^{\circ} \mathrm{C}$, the medium was assayed for degraded elastin (soluble radioactivity). Data represent the average results of separate experiments using cells from each of five subjects (smokers). The coefficient of variation for elastin degradation by live cells from the five subjects was $21 \%$. The data are expressed as nanograms $\left[{ }^{3} \mathrm{H}\right]$ elastin released per $10^{6}$ cells. Elastin released by porcine pancreatic elastase or human plasmin is shown for comparison. ND, not determined.

We next examined the role cell contact might have in elastin degradation by intact alveolar macrophages in identical experiments to those done with fibrin (Table II). Cells were cultured for $24 \mathrm{~h}$ either in contact with or remote from a [ $\left.{ }^{3} \mathrm{H}\right]$ elastin substratum. The data in Table IV show that much greater elastinolysis occurred when cells were in contact with the matrix. The extent of elastinolysis by macrophages cultured on the substrate was 20 - and 400 -fold higher than that of cells cultured off elastin for assays done in fetal bovine serum and human serum, respectively. The data also indicate that when cells are incubated in contact with the substrate, the presence of serum proteinase inhibitors ( $1 \%$ fetal bovine serum or $1-10 \%$ human serum) had only a weak effect on the extent of elastinolysis. There was an $\sim 20 \%$ decrease in elastolytic activity in media containing $1-10 \%$ human serum as compared with cultures done in media depleted of proteinase inhibitors by acidification.

Data in both Tables III and IV also show that the addition of plg to cultures of human macrophages in contact with purified elastin measurably increased elastin degradation. In nine separate experiments, plg increased elastin solubilization by an average of $30 \%$. This increase was statistically significant, $P<0.005$, using a paired $t$ test (35). The mechanism of the plasmin effect on human macrophage elastin degradation is unclear. As stated above, plasmin alone did not measurably increase elastin solubilization. In separate studies of stimulated murine peritoneal macrophages, we observed plasmin to enhance intact cell elastin degradation to a much greater extent, i.e., 2- to 10-fold (Chapman, H. A., and O. L. Stone, manuscript submitted for publication). In this case the plasmin enhancement appears to be due to plasmin activation of latent macrophage elastase activity. However, we have no direct evidence that human macrophages express or secrete a latent elastase.

Whether or not human macrophages express a latent elastase, live macrophage elastinolysis does not exclusively reflect the activity of a single enzyme. The addition of the lysosomal inhibitor chloroquine, 25-50 $\mu \mathrm{M}$, to the medium over macrophages from each of the five subjects reported in Table III inhibited $\left[{ }^{3} \mathrm{H}\right]$ elastin degradation by $25-35 \%$. Similarly, cytochalasin $\mathrm{B}, 5 \mu \mathrm{M}$, at concentrations that block phagocytosis, inhibited release $30-35 \%$ (data not shown). These findings indicate that a fraction, $<40 \%$, of the elastin solubilization by alveolar macrophages depends on intracellular proteolysis. Additional experiments with inhibitors of metallo-, thiol, or serine proteinases also indicated that elastin solubilization by live cells involves multiple proteinases. Using macrophages from five smoking subjects and culture condition described in Table III, but with $\mathrm{Ca}^{++}-\mathrm{Mg}^{++}$-free DME, we observed EDTA, $0.1 \mathrm{mM}$, to inhibit elastin degradation by an average of $50 \%$ (range, 40-65\%). Either the thiol proteinase inhibitor Z-phenyl-alanyldiazomethylketone, $10^{-5} \mathrm{M}$, or the neutrophil elastase inhibitor, succinyl-analyl-alanyl-prolyl-valyl-chloromethylketone, $0.1 \mathrm{mM}$, inhibited elastin solubilization in these five subjects $65-75 \%$ $(36,37)$. These findings are consistent with a cooperative process

Table IV. Effect of Cell Contact and Serum Proteinase Inhibitors on $\left[{ }^{3} \mathrm{H}\right]$ Elastin Degradation by Intact Human Alveolar Macrophages

\begin{tabular}{|c|c|c|}
\hline \multirow[b]{2}{*}{ Serum added to basic tissue culture medium } & \multicolumn{2}{|c|}{$\begin{array}{l}{\left[{ }^{3} \mathrm{H}\right] \text { Elastin degraded }} \\
(\mathrm{ng} / 24 \mathrm{~h})\end{array}$} \\
\hline & $\begin{array}{l}\text { Cells contacting } \\
\text { elastin }\end{array}$ & $\begin{array}{l}\text { Cells remote } \\
\text { to elastin }\end{array}$ \\
\hline $1 \%$ acid-treated, plg-free dog serum & 4,555 & 722 \\
\hline \multicolumn{3}{|l|}{$1 \%$ acid-treated, plg-free dog serum } \\
\hline plus plg, $8 \mu \mathrm{g} / \mathrm{ml}$ & 6,199 & 839 \\
\hline $1 \%$ fetal bovine serum & 4,808 & 235 \\
\hline \multicolumn{3}{|l|}{$1 \%$ human serum, MM } \\
\hline$\alpha_{1}$-antitrypsin phenotype & 4,048 & 10 \\
\hline \multicolumn{3}{|l|}{$10 \%$ human serum, MM } \\
\hline$\alpha_{1}$-antitrypsin phenotype & 4,050 & 9 \\
\hline
\end{tabular}

Intact human alveolar lavage cells ( $10^{6}$ cells, $>95 \%$ macrophages) were cultured in tissue culture chambers coated with $\left[{ }^{3} \mathrm{H}\right]$ elastin. The cells were cultured either on or off the elastin substratum. After incubation for $24 \mathrm{~h}$ in $500 \mu \mathrm{l}$ DME supplemented with various sera, cellfree supernates were assayed for degraded elastin. Data are expressed as nanogram elastin solubilized $/ 24 \mathrm{~h}$ per $10^{6}$ cells. Cells for the experiment shown were obtained from a smoking individual. Similar results were observed in three additional experiments using cells from two smokers and one nonsmoker. In all cases, neutrophils represented $<2 \%$ of the total recovered alveolar cells. 
involving a metalloproteinase, typical of macrophage elastase (32), a thiol proteinase, and possibly a neutrophil elastase. The neutrophil elastase could be bound to or released from alveolar macrophages following uptake in vivo as reported by White et al. (38). However, experiments with these inhibitors must be interpreted cautiously, as we have not isolated any of the human enzymes involved in elastinolysis and the inhibitors are not specific. Some chloromethylketones, for example, inactivate thiol proteinases (39). The mechanisms of elastin degradation by live human cells and the enzyme sources require further study.

\section{Discussion}

Mason et al. (40) previously reported PA activity in all preparations of human macrophages teased from surgical specimens of lung resected for pulmonary malignancy. The authors did not determine whether the PA activity was secreted or cell associated. The results reported in this study also indicate that human alveolar macrophages express PA activity (Fig. 1). The fact that cells freshly lavaged from seven healthy, nonsmoking individuals all expressed PA activity within $4 \mathrm{~h}$ in vitro culture suggests PA is a normal function of alveolar macrophages. The results further show that the human alveolar macrophage PA is largely, under some conditions entirely, cell associated (Table I).

As the data in Fig. 1 indicate, there is a small but consistent release of ${ }^{125} \mathrm{I}$ (5-10\% of total label) by intact alveolar macrophages after $4 \mathrm{~h}$ at $37^{\circ} \mathrm{C}$ even in the absence of added plg. This is confirmed in the 18-h fibrinolytic assay (Table II) where cells released $\sim 25 \%$ of the total label when cultured on ${ }^{125}$ I-fibrin in the absence of plg. However, macrophages maintained on plg-free fibrin for $24-48 \mathrm{~h}$ did not progressively degrade the fibrin as judged visually and the ${ }^{125}$ I release did not increase linearly with time. We are therefore not convinced that the ${ }^{125} \mathrm{I}$ release in the absence of plg entirely reflects proteolysis. Although macrophages may well degrade fibrin at low rates by plg-independent mechanisms, the released ${ }^{125}$ I could also be due to iodase activity. Ragsdale and Arend (27) reported that human monocytes release an iodase. We have not pursued this possibility with human alveolar macrophages.

Previous investigations of a number of isolated cell types as well as extracted tissue preparations have chemically characterized PA as either urokinase-like or tissue activatorlike $(3,4$, 21). This is based on the different molecular mass (50-55 kD vs. $65-70 \mathrm{kD}$, respectively) as well as different immunospecifities of PA purified from human urine (urokinase) or uterine tissue $(21,41)$. These differences in physical properties are reflected in different biological properties. Tissue activator is bound and activated by fibrin, whereas urokinase is not (14). Most characterizations of cell or tissue PA derive from studies of secreted PA, into culture media, but where compared the cell-associated and secreted forms have been similar $(22,42)$. Our data indicate that human alveolar macrophages synthesize a single species of catalytically active PA, which is urokinase-like. The apparent molecular mass of active PA is indistinguishable from that of purified urokinase in nonreduced SDS gels (Fig. 2) and the enzyme activity is neutralized specifically by urokinase antibody (Fig. 3). Independently, Bowen et al. (43) recently reached a similar conclusion. We further show here that alveolar macrophages actually synthesize urokinase-like PA as judged by immunoprecipitation of membrane fractions of metabolically labeled cells (Fig. 4).

The membrane location of PA activity has implications for the mechanisms of fibrinolysis by macrophages. First, the PA itself in a membrane location is likely to be relatively resistant to soluble protease inhibitors (13). This may be important in that human as well as murine macrophages can release an inhibitor of urokinase-like PA $_{\mathrm{s}}$ (44). Second, the activation of plasmin is confined to the cell surface. Thus, although soluble urokinase does not bind to fibrin, its cell-associated location on macrophages allows for juxtaposition of the enzyme to fibrin via the cell. Although plasmin itself does not bind to macrophages, plasmin does tightly bind to fibrin and once bound has a threefold drop in its sensitivity to antiplasmins. The binding of plasmin to fibrin rather than to antiplasmins is likely to occur if macrophages, bound to fibrin and expressing a membrane PA, activate plasmin near the cell-fibrin interface. This series of events explains the fibrinolysis mediated by human macrophages in contact with fibrin even in the presence of serum proteinase inhibitors (Table II). Predictably, when macrophages were remote to the fibrin but cultured in the presence of proteinase inhibitors, much less fibrinolysis occurred. In this case, plasmin formed near the cell surface is largely neutralized by antiplasmins before binding fibrin.

It must be considered that this capability of macrophages to focus protein degradation at or near the cell surface even in the presence of soluble proteinase inhibitors may not be unique for fibrin. Plasmin has a wide spectrum of substrates including fibronectin, laminin, and other glycoproteins that are normal components of the extracellular matrix (45-47). Other neutral proteinases such as soluble elastase also bind tightly to their substrates (48). If these proteinases are also bound to the cell surface, or released by macrophages near the substrate, proteolysis could eventuate even in the presence of soluble proteinase inhibitors. We observed this in fact to be the case with intact macrophage elastin degradation (Table IV). In this experiment, appreciable elastinolysis only occurred when the macrophages contacted the elastin. When the cells contacted the substrate, however, elastinolysis occurred even in the presence of $10 \%$ human serum. Whether or not the elastase activity expressed by alveolar macrophages is released into the medium and/or is bound to the cell surface is unclear at this point. Campbell et al. (49) have reported a relative insensitivity of intact neutrophil proteolysis to proteinase inhibitors when these cells were in contact with fibronectin. Current concepts suggest that a balance between soluble proteinases and proteinase inhibitors is important to the homeostasis of lung architecture and that an imbalance in favor of proteinases mediates alveolar wall destruction that eventuates in emphysema (50). The findings reported here of fibrinolysis and elastinolysis by intact human 
alveolar macrophages, if generalized, would suggest that the proper topology among cells, substrates, and inhibitors could result in matrix degradation regardless of the balance between proteinases and inhibitors in the soluble phase. Still, a deficiency of soluble proteinase inhibitors would likely accelerate the degradative process. The rates of fibrin or elastin degradation by intact macrophages were higher in media depleted of proteinase inhibitors.

Werb et al. (47, 52) and Jones et al. (51) have reported a series of experiments examining the degradative mechanisms of live murine macrophages cultured on extracellular matrices deposited in vitro by smooth muscle cells. They metabolically labeled whole matrices with $\left[{ }^{3} \mathrm{H}\right]$ proline and monitored degradation of individual components, i.e., glycoproteins, collagen, or elastin, by macrophages, as the difference in label released by macrophages and that released by specific enzymes, i.e., trypsin, collagenase, or elastase. They observed that pretreatment of intact matrices with trypsin or plasmin or incubation of cells on matrices with added plg accelerated the breakdown of elastin components by the macrophages. They further observed that much of the matrix degradation occurred in pericellular locations and that elastase activity of live cells as compared with soluble elastase was relatively resistant to inhibition by $\alpha$-2-macroglobulin. Our data support these findings. We developed an assay of intact macrophage elastinolysis of purified insoluble elastin (Chapman, H. A., and O. L. Stone, manuscript submitted for publication). We observed that when the elastin was mixed with fibrin, the addition of plg was critical to the elastin degradation by alveolar lavage cells (Table III) although plasmin only weakly accelerated elastin degradation by macrophages on pure elastin and had no effect on elastin in the absence of cells. Similarly, contact of the macrophages with the elastin was critical to elastinolysis (Table IV), but intact cells in contact with elastin could measurably degrade elastin even in the presence of serum proteinase inhibitors. Together, these data suggest that plasmin, and therefore macrophage PA, have integral roles in matrix metabolism by alveolar macrophages. This extends beyond the purpose of simply resolving tissue fibrin to include the degradation of tissue proteins toward which plasmin has no direct proteolytic effect. Indeed in some cases, as shown in Table IV, PA and plg, not elastase, may be rate limiting in elastin degradation. This may be important to the movement of lung macrophages within normal interstitial tissues of the lung and may be relevant to the destruction of lung tissue common to a number of inflammatory processes in which alveolar macrophages are prominent.

\section{Acknowledgments}

We thank Renee Christiansen and Linda Douglas for help with the work and Gwenevere Shaw for help in preparation of the manuscript. We also thank Dr. Stephen Wright and Dr. Jerry Kaplan for helpful discussions.

This work was supported by the National Institutes of Health grant R01 HL28577-02 and by the Veterans Administration.

\section{References}

1. Human Blood Coagulation, Haemostasis, and Thrombosis. 1976. R. Biggs, editor. Blackwell Scientific Publications. 399-435.

2. Todd, A. S. 1959. The histologic localization of fibrinolysis activator. J. Pathol. Bacteriol. 78:281-283.

3. Binder, B. R., J. Spragg, and K. F. Austen. 1979. Purification and characterization of human vascular plasminogen activator cleaved from blood vessel perfusates. J. Biol. Chem. 254:1998-2003.

4. Wun, T., L. Ossowski, and E. Reich. 1982. A proenzyme form of human urokinase. J. Biol. Chem. 257:7262-7268.

5. Greineder, D. K., K. J. Connorton, and J. R. David. 1979. Plasminogen activator production by human monocytes. J. Immunol. 123:2808-2812.

6. Granelli-Piperno, A., J. Vassalli, and E. Reich. 1977. Secretion of plasminogen activator by human polymorphonuclear leukocytes. $J$. Exp. Med. 146:1693-1706.

7. Valinsky, J. E., E. Reich, and N. M. Le Dovarin. 1981. Plasminogen activator in the Bursa of Fabricius: correlations with morphogenetic remodeling and cell migrations. Cell. 25:471-476.

8. Moonen, G., M. P. Grau-Wagemans, and I. Selak. 1982. Plasminogen activator-plasmin system and neuronal migration. Nature (Lond.). 298:753-755.

9. Beers, W. H., S. Strickland, and E. Reich. 1975. Ovarian plasminogen activator: relationship to ovulation and hormonal regulation. Cell. 6:387-394.

10. Vassalli, J., J. Hamilton, and E. Reich. 1978. Macrophage plasminogen activator: modulation of enzyme production by anti-inflammatory steroids, mitotic inhibitors, and cyclic nucleotides. Cell. 280:271281.

11. Unkeless, J. C., S. Gordon, and E. Reich. 1974. Secretion of plasminogen activator by stimulated macrophages. J. Exp. Med. 139:834849.

12. Vassalli, J., and E. Reich. 1977. Macrophage plasminogen activator: induction by products of activated lymphoid cells. J. Exp. Med. 145:429-437.

13. Chapman, H. A., Z. Vavrin, and J. B. Hibbs. 1982. Macrophage fibrinolytic activity: identification of two pathways of plasmin formation by intact cells and of a plasminogen activator inhibitor. Cell. 28:653662.

14. Wiman, B., and D. Collen. 1978. Molecular mechanism of physiological fibrinolysis. Nature (Lond.). 272:549-550.

15. Sandberg, L. B., N. T. Soskel, and N. Leslie. 1981. Elastin structure, biosynthesis, and relation to disease states. N. Engl. J. Med. 304:566579.

16. Reynolds, H. Y., and H. H. Newball. 1974. Analysis of proteins and respiratory cells obtained from human lungs by bronchial lavage. J. Lab. Clin. Med. 84:559-573.

17. Papermaster-Binder, G., M. E. Whitcomb, and A. L. Sagose, Jr. 1980. Characterization of the metabolic response of human pulmonary alveolar macrophages. J. Reticuloendothel. Soc. 28:129-139.

18. Kaplan, J., and M. Nielsen. 1979. Analysis of macrophage surface receptors. J. Biol. Chem. 254:7323-7328.

19. Mosesson, M. W. 1962. The preparation of human fibrinogen free of plasminogen. Biochim. Biophys. Acta. 57:204-213.

20. Gordon, S., Z. Werb, and Z. A. Cohn. 1976. Methods for detection of macrophage secretory enzymes. In In Vitro Methods in Cell-Mediated and Tumor Immunity. E. B. Bloom and J. R. David, editors. Academic Press, Inc., New York. 341-352. 
21. Vetterlein, D., P. L. Young, T. E. Bell, and R. Roblin. 1979. Immunological characterization of multiple molecular weight forms of human cell plasminogen activators. J. Biol. Chem. 254:575-578.

22. Quigley, J. P. 1976. Association of a protease (plasminogen activator) with a specific membrane fraction isolated from transformed cells. J. Cell Biol. 71:472-483.

23. Laemmli, Y. K. 1970. Cleavage of structural proteins during assembly of the head of bacteriophage $\mathrm{T}_{4}$. Nature (Lond.). 277:680685.

24. Fowler, W. E., R. R. Hantgan, J. Hermans, and H. P. Erickson. 1981. Structure of the fibrin protofibril. Proc. Natl. Acad. Sci. USA. 78:4872-4876.

25. Cullen, S. E., and B. D. Schwartz. 1976. An improved method for isolation of $\mathrm{H}-2$ and Ia alloantigens with immunoprecipitation induced by protein A-bearing staphylococci. J. Immunol. 117:136-142.

26. Lowry, D. H., N. J. Rosenbrough, A. L. Farr, and R. J. Randall. 1951. Protein measurement with the Folin phenol reagent. J. Biol. Chem. 193:265-275.

27. Ragsdale, C. G., and W. P. Arend. 1979. Neutral protease secretion by human monocytes. J. Exp. Med. 149:954-968.

28. Levin, E. G., and D. J. Loskutoff. 1980. Serum-mediated suppression of cell-associated plasminogen activator activity in cultured endothelial cells. Cell. 22:701-707.

29. Chapman, H. A., Z. Vavrin, and J. B. Hibbs. 1979. Modulation of plasminogen activator secretion by activated macrophages: influence of serum factors and correlation with tumoricidal potential. Proc. Natl. Acad. Sci. USA. 76:3899-3903.

30. Hinman, L. M., C. A. Stevens, R. A. Matthay, and J. Bernard Gee. 1980. Elastase and lysozyme activities in human alveolar macrophages. Am. Rev. Respir. Dis. 121:263-271.

31. Fuks, A, D. Zucker-Franklin, and E. C. Franklin. 1983. Identification of elastases associated with purified plasma membranes isolated from human monocytes and lymphocytes. Biochim. Biophys. Acta. 755:195-203.

32. Sandhaus, R. A., K. M. McCarthy, R. A. Musson, and P. M. Henson. 1983. Elastolytic proteinases of the human macrophages. Chest. 83:60S-62S.

33. Green, M. R., J. S. Lin, L. B. Berman, M. M. Osman, J. M. Cerreta, I. Mandl, and G. M. Turino. 1979. Elastolytic activity of alveolar macrophages in normal dogs and human subjects. J. Lab. Clin. Med. 94:549-562.

34. Levine, E. A., R. M. Senior, and J. V. Butler. 1976. The elastase activity of alveolar macrophages: measurements using synthetic substrates and elastin. Am. Rev. Respir. Dis. 113:25-30.

35. T. Colton. 1974. Statistics in Medicine. Little, Brown, and Co., Boston, MA. 127-134.

36. Green, C. D. G., and E. Shaw. 1981. Peptidyl diazomethylketones are specific inactivators of thiol proteinases. J. Biol. Chem. 256:19231928.

37. Powers, J. C., B. F. Gupton, A. D. Harley, N. Nishino, and R. J. Whitley. 1977. Specificity of porcine pancreatic elastase, human leukocyte elastase, and cathepsin G. Inhibition with peptide chloromethylketones. Biochim. Biophys. Acta. 485:156-166.

38. White, R., A. Janoff, R. Gordon, and E. Campbell. 1982. Evidence for in vivo internalization of human leukocyte elastase by alveolar macrophages. Am. Rev. Respir. Dis. 125:779-781.

39. Barrett, A. J. 1974. Cathepsin $B_{1}$. A lysosomal enzyme that degrades native collagen. Biochem. J. 137:387-398.

40. Mason, R., J. Austyn, F. Brodsky, and S. Gordon. 1982. Monoclonal antimacrophage antibodies: human pulmonary macrophages express HLA-DR (Ia-like) antigens in culture. Am. Rev. Respir. Dis. 125:586-593.

41. Holmberg, L., B. Bladh, and B. Ostedt. 1976. Purification of urokinase by affinity chromatography. Biochim. Biophys. Acta. 445:215222.

42. O'Donnell-Tormey, J., and J. P. Quigley. 1981. Inhibition of plasminogen activator release from transformed chicken fibroblasts by a protease inhibitor. Cell. 27:87-95.

43. Bowen, R. M., R. D. Estensen, and J. R. Hoidal. 1983. Presence of plasminogen activator in lower respiratory tract of hamsters and humans. Am. Rev. Respir. Dis. 127:280A. (Abstr.)

44. Chapman, H. A., and Z. Vavrin. 1983. Normal human alveolar macrophages secrete a proteinase inhibitor. Clin. Res. 31:71A. (Abstr.)

45. Balian, G., E. M. Click, E. Crouch, J. M. Davidson, and P. Bornstein. 1979. Isolation of a collagen-binding fragment from fibronectin and cold-insoluble globulin. J. Biol. Chem. 254:1429-1432.

46. Liotta, L. A., R. H. Goldfarb, and V. P. Terranova. 1981. Cleavage of laminin by thrombin and plasmin: alpha thrombin selectively cleaves the beta chain of laminin. Thromb. Res. 21:663-673.

47. Werb, Z., M. J. Banda, and P. A. Jones. 1980. Degradation of connective tissue matrices by macrophages. I. Proteolysis of elastin, glycoproteins, and collagen by proteinases isolated from macrophages. J. Exp. Med. 152:1340-1357.

48. Banda, M., and Z. Werb. 1981. Mouse macrophage elastase. Purification and characterization as a metalloproteinase. Biochem. J. 193:589-605.

49. Campbell, E. J., R. M. Senior, J. A. McDonald, and D. L. Cox. 1982. Proteolysis by neutrophils. Relative importance of cell-substrate contact and oxidative inactivation of proteinase inhibitors in vitro. $J$. Clin. Invest. 70:845-852.

50. Snider, G. L., 1981. The pathogenesis of emphysema-twenty years of progress. Am. Rev. Respir. Dis. 124:321-324.

51. Jones, P. A., and Z. Werb, 1980. Degradation of connective tissue matrices by macrophages. II. Influence of matrix composition on proteolysis of glycoproteins, elastin, and collagen by macrophages in culture. J. Exp. Med. 152:1527-1536.

52. Werb, Z., D. F. Bainton, and P. A. Jones. 1980. Degradation of connective tissue matrices by macrophages. III. Morphological and biochemical studies on extracellular, pericellular, and intracellular events in matrix proteolysis by macrophages in culture. J. Exp. Med. 152:15371553. 